\title{
4D4
}

\section{枌体の流動化水平輸送の輸送特性 \\ Transportation characteristics of fluidized powder conveying in a horizontal channel}

\author{
学 O山下 純人（大分高専） 学 廣瀬 智也（大分高専） \\ 正 尾形 公一郎 (大分高専)
}

Sumito YAMASHITA, National Institute of Technology, Oita College, 1666 Maki, Oita

Tomoya HIROSE, National Institute of Technology, Oita College

Koichiro OGATA, National Institute of Technology, Oita College

Key Words: Fluidization, Powder conveying, Particle, Fluidizing velocity, Mass flow rate, Solid loading ratio

\section{1. 緒五}

一般に，粉体層の底部に均一な空気を送りこむと粒子間 力, 粒子一壁面間力が低減して流動化が生じ, 粉体の流動 性が向上することが知られている。この操作を用いた粉体 の高浱度輸送方法にエアスライド輸送がある(1)。この方法 は水平面に対して任意の傾斜角を有する輸送管内で粉体を 流動化させて輸送する．粉体の大量輸送が可能で，消損亜 力や粉体の摩耗が少ないなどの利点はあるが，輸送時の粉 体に重力成分を与えるために輸送管に傾斜角を設ける必要 があるとされている. 加えて，粉体の流動化輸送では水平 輸送が原理上不可能と言われており，この輸送方法の使用 用途は制限されているのが現状である。そこで，筆者らは 流動化を用いた粉体の水平輸送の研究を進めてきた沟-(3).

これまでの研究では，粒子密度がほぼ一定で粒子径の異 なる 2 種類のガラスビーズを用いて, 輸送装置の供給容器 と輸送管の底部に供給する空気速度を変化させた場合の輸 送特性を調査した。 その結果, 両粒子ともに, 供給容器底 部一空気を供給し, 輸送管底部一最小流動化速度以上の空 気を与えることで粉体の流動化水平輸送が可能であること が確認された.また, 被輸送粉体の粒子径が大きくなると， 単位時間当たりの輸送䔔と混合比が低下することが分かっ た。しかしながら, 粒子密度が異なる粉体の流動化輸送特 性の知見は得られていない.

そこで，本研究では，ガラスビーズと粒子径がほぼ同等 で粒子密度の異なる PVCを使用して, 粉体の流動化水平輸 送実験を行った，既報(4)では，供給容器底部への空気速度 が一定で輸送管底部に供給する空気速度を変化させた場合 の粉体輸送特性を報告した，本報では，供給容器底部の空 気速度を変化させた場合のPVCの輸送特性を述べる。

\section{2. 实験方法}

Fig.1 に流動化水平輸送装置の概略を示す. 本輸送装置は 粉体供給容器と矩形水平輸送管から成る. 供給容器はアク リル製円筒容器で, 内径 $241 \mathrm{~mm}$, 高さ $1000 \mathrm{~mm}$ である. 輸 送管もアクリル製で，輸送距倠 $1000 \mathrm{~mm}, 1$ 辺 $30 \mathrm{~mm}$ の正 方形断面である。供給容器底部と輸送管底部には厚さ $6 \mathrm{~mm}$ の多孔材を取り付けている。粉体輸送に使用する空気はコ ンプレッサで生成し，マスフローコントローラで流量設定 を行う。粉体輸送量はロードセルで測定し, 供給容器底部, 輸送管底部と回収器底部に設置した. 圧力測定には圧力セ ンサを使用し，供給容器と輸送管の底部に設㽞した。供給 容器内の粉体層高さはレーザー変位計で測定した，供給容 器内と輸送管内の粉体のフローパターンはデジタルビデオ カメラで撮影した。

実験は，粉体を供給容器に充てんした後，供給容器底部 に空気を供給して粉体層を一時的に流動化させ，粉体層上 部を供給容器底部に対して水平にする. その後, 流量設定
した空気を供給容器と輸送管の底部に同時に送り込み, 供 給容器内の粉体が水平輸送管を流れて回収器へ輸送される.

\section{3. 英険条件}

本実験では平均粒子直径 $d_{p}=151 \mu \mathrm{m}$, 真密度 $\rho_{p}=1382 \mathrm{~kg} / \mathrm{m}^{3}$, 最小流動化速度 $u_{m f}=9.0 \mathrm{~mm} / \mathrm{s}$ の PVCを使用した。

Tablel に実験条件を示す. 表中の $M_{p i}$ は粉体の初期充て ん墨， $u_{h}$ は供給容器底部の空気速度， $u_{t}$ は輸送管底部の空 気速度を表している. 本研究では， $u_{h}$ と $u_{t}$ を $u_{m f}$ で無次元 化した值をパラメータとした．また， $u_{h}$ と $u_{t}$ は供給容器と 輸送管の底部に供給する空気流量を，それぞれの通過断面 稹で除した值である。

\section{4. 英䤣結果と考察}

Fig.2に粉体輸送量 $M_{p i}$ の時間変化を示す. 輸送粉体はPVC, $u_{h} / u_{m f}=0.844, u_{t} / u_{m f}=0.898 \sim 3.85$ である. Fig.3に $u_{h} / u_{m f}$ と $u_{t} / u_{m f}$ を変化させた場合のPVCの輸送状態の判定結果を示す。こ こで，本研究では，既報 ${ }^{(3)}$ と同様にFig.2の粉体輸送量の時 間変化の結果からFig.3の輸送判定を行った。まず, Fig.2の $u_{t} / u_{m f}=0.898,1.0270$ 条件では, 粉体の輸送は行われている が十分な粉体輸送量が得られていない。このため，十分な 流動化輸送が得られない条件として，Fig.3にவで示した。 次に, Fig. $20 u_{\mathrm{f}} / u_{m f}=1.283,1.581$ の条件では，空気の供給開 始後に粉体輸送毁が急速に増加し，徐々に傾きが減少する 分布を示す.この輸送特性を輸送の道移条件としてFig.3に

○で示した．また，Fig.2の $u_{t} / u_{n j} \geq 2.567$ 条件では，粉体輸

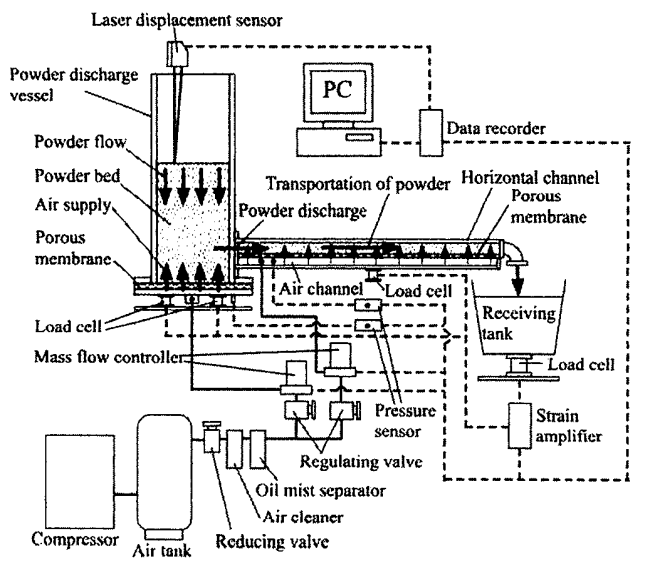

Fig.1 Experimental apparatus

Table 1 Experimental conditions

\begin{tabular}{|c|c|}
\hline Initial mass of powder $M_{p i}[\mathrm{~kg}]$ & 11 \\
\hline Fluidizing velocity of vessel $u_{h} / u_{m f}[-]$ & $0 \sim 1.519$ \\
\hline Fluidizing velocity of channel $u_{t} / u_{m f}[-]$ & $0.898 \sim 3.85$ \\
\hline
\end{tabular}


送量の時間変化の分布形に変化が見られなくなる。この輸 送特性は既報 ${ }^{(2)-(3)}$ と同様であり，円滑な輸送が可能な条件 として Fig.3 に○で示した。 さらに，粉体輸送が行えなか った条件は Fig.3に×で示した.

Fig.3 の結果から，本実験で使用した PVC も既報(2)-(3) と 同様に，供給容器底部に空気を供給し，なおかつ輸送管底 部に最小流動化速度以上の空気を供給する条件で円滑な流 動化水平輸送が可能であることが確認された.

Fig.4に単位時間当たりの最大輸送战 $G_{\text {smax }}$ と輸送管底部 の空気速度 $u_{t} / u_{m f}$ の関係を示す。ここで, 供給容器底部の 空気速度 $u_{h} / u_{m f}$ も変化した. 図中の $G_{s m a x}$ は各実龆の輸送開 始から 2.5 秒ごとの輸送早の傾きの最大值である. 図より, $u_{h} / u_{m f}$ が一定の条件では， $G_{s m a x}$ は $u_{t} / u_{m f}=1 \sim 1.6$ の条件で $u_{t} / u_{m f}$ の増加とともに増加し, その後は $G_{\text {smax }}$ の大幅な增加 は見られない.また， $G_{\text {smax }}$ の大幅な増加が見られない領域 では， $u_{h} / u_{m f}$ の増加とともに $G_{\text {smax }}$ が増加し， $u_{h} / u_{m f}>1$ の条 件では $G_{\text {smax }}$ が同等の值を取る傾向を示した。

Fig. 5 に輸送管底部の空気速度 $u_{t} / u_{m f}$ と供給容器底部の空 気速度 $u_{h} / u_{m f}$ を変化させた場合の最大混合比 $m_{\max }$ を示す. ここで, $u_{t} / u_{m f}$ と $u_{h} / u_{m f}$ の変化は Fig.4 と同一である.また, 最大混合比は単位時間当たりの最大輸送量を輸送時に供給 した空気の全質量流量で除した值であり，これは粉体の輸 送効率として考えることができる. 図より, $m_{\max }$ は $u_{\downarrow} / u_{m f}=1$ 〜1.6の条件で急激に増加することが確認できる. その後, $m_{\max }$ は $u_{t} / u_{m f}=1.6$ 付近で最大值を取り, $u_{t} / u_{m f}$ の増加ととも に減少する傾向を示す.また, $u_{h} / u_{m,} \geq 0.844$ の条件において, $m_{\text {max }}$ の $u_{r} u_{m f}$ に対する分布形が類似する傾向が確認された.

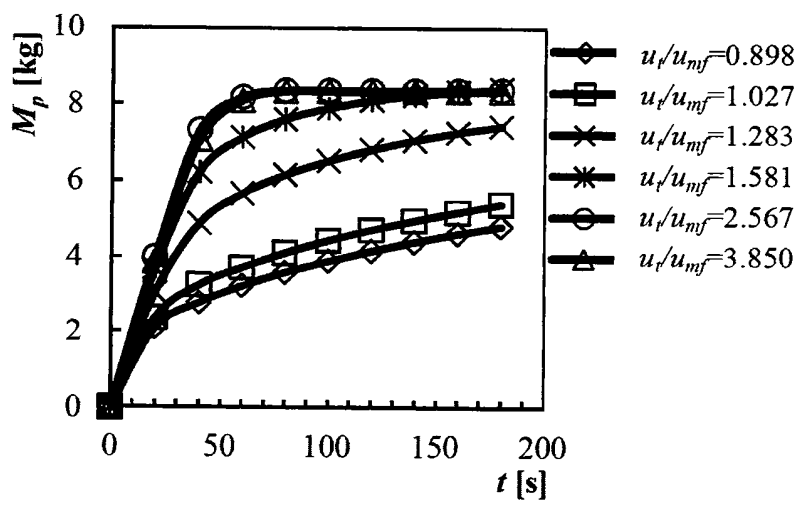

Fig.2 Time histories of the mass of transported powder $\left(\mathrm{PVC}, u_{h} / u_{m \digamma}=\mathbf{0 . 8 4 4}\right)$

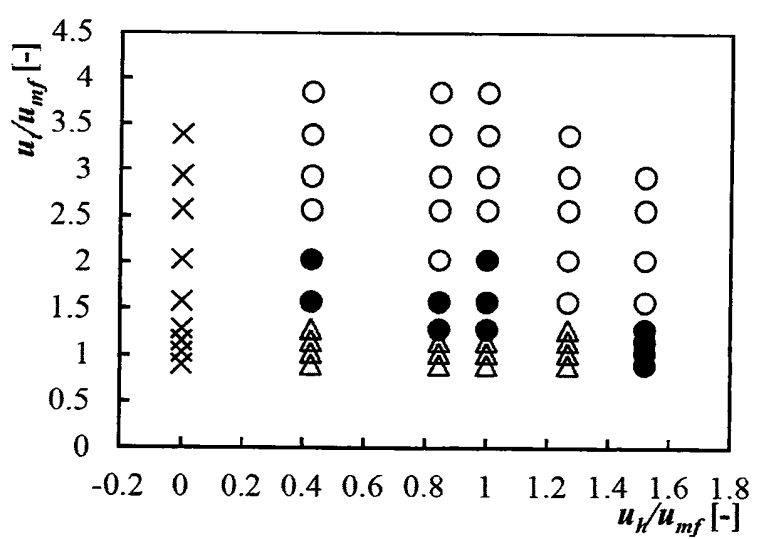

Fig.3 The state of powder conveying of PVC with the fluidizing velocity at the bottom of the vessel and the channel
これらの結果は, 本輸送装孟の供給容器と輸送管の底部一 供給する空気速度を増加させても，必ずしも輸送効率が増 加する訳ではないことを意味している．さらに，本実験条 件の範囲内では, $u_{h} / u_{m f}=1.266, u_{t} / u_{m f}=1.581$ の条件で輸送効 率の最大值を示し，その值は 400 程度で高濃度輸送が実現 できていることが確認された.

\section{5. 結苗}

本砳究では, 輸送装筑の供給容器と輸送管の底部に供給 する空気速度を変化させた場合の PVC 粉体の流動化水平 輸送実输を行い，次の結果が得られた。

(1) PVCにおいても, 供給容器底部に空気を供給した状 態で, 䩱送管底部に最小流功化速度以上の空気を供給する と円滑な流動化水平輸送が実現できることが分かった。

(2) 供給容器や輸送管の底部へ供給する空気速度を増加 させても，単位時間当たりの最大輸送量や最大混合比は必 ずしも増加しない傾向が確認された。

\section{奉考文献}

(1) Klinzing, G. E. et al., Pneumatic conveying of solids, Chapman and Hall, 340-347 (1999)

(2) Ogata et al., Advanced Powder Tech., 23-6, pp.761-770 (2012)

(3) 磨瀨・山下・尾形, 混相流シンポジウム 2014 講演論 文集 on USB，D233，pp.1-2(2014)

(4) 山下・穈瀬 - 尾形, 日本機械学会九州学生会第 45 回 卒業研究発表講演論文集, No.148-2, pp.413-414(2014)

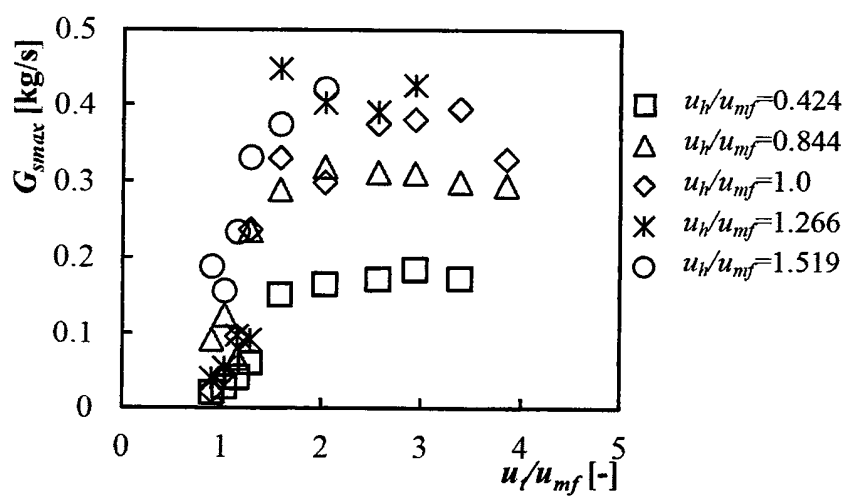

Fig.4 Relationship between the maximum mass flow rate of PVC powder and the fluidizing velocity at the bottom of the vessel and the channel of the PVC

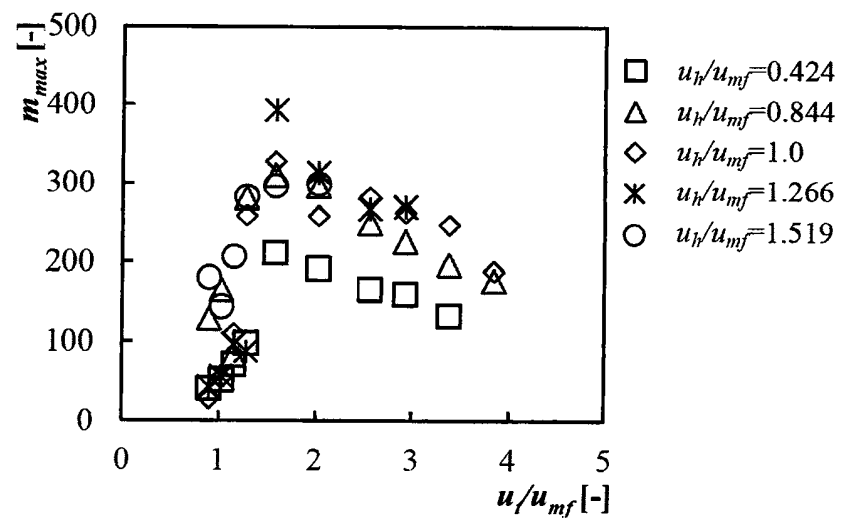

Fig.5 Relationship between the maximum solid loading ratio of $P V C$ powder and the fluidizing velocity at the bottom of the vessel and the channel 